\title{
Rancangan Sistem Pendukung Keputusan Pemilihan Jurusan Pada Fakultas Ilmu Komputer Menggunakan Metode Analytical Hierarchy Process (Studi Kasus Universitas Banten Jaya)
}

\author{
Rudianto ${ }^{1}$, Ramdani Budiman² \\ Email : rudianto@unbaja.ac.id ${ }^{1,}$ ramdani.budiman@unbaja.ac.id ${ }^{2}$ \\ Program Studi Teknik Informatika, Universitas Banten Jaya ${ }^{1,2}$
}

\begin{abstract}
Abstrak
Universitas Banten Jaya adalah salah satu perguruan tinggi swasta di Banten yang menawarkan berbagai jurusan, memberikan berbagai informasi menarik bagi calon mahasiswa baru antara lain akreditasi, biaya, prospek setelah lulus, dan keinginan mahasiswanya. Hal ini membuat calon mahasiswa kesulitan dalam menentukan jurusan yang sesuai dan tepat di Universitas Banten Jaya terutama pada Fakultas Ilmu Komputer. Dari analisa sistem yang berjalan perlu dirancang sistem pendukung keputusan dalam memilih jurusan pada Fakultas Ilmu Komputer Universitas Banten Jaya, yang dapat membantu calon mahasiswa baru menentukan jurusan yang akan mereka tentukan. Perancangan aplikasi ini menggunakan metode AHP (Analytical Hierarchy Process) untuk membantu perhitungan pendukung keputusan.. Hasil dari penelitian ini berupa aplikasi sistem pendukung keputusan dengan menggunakan metode AHP (Analytic Hierarchy Process) berbasis web untuk memudahkan calon mahasiswa baru Fakultas Ilmu Komputer dalam memilih jurusan yang sesuai dengan harapannya.
\end{abstract}

Kata Kunci : Sistem Pendukung Keputusan, Analitical Hierarchy Process, Jurusan, Mahasiswa

\section{Pendahuluan}

Universitas Banten Jaya merupakan salah satu perguruan tinggi swasta di Provinsi Banten yang mempunya 3 fakultas, salah satunya adalah Fakultas Ilmu Komputer (FILKOM). Filkom memiliki 5 jurusan di antaranya Teknik Informatika-S1, Teknik Informatika-D3, Sistem Informasi-S1, Manajemen Informatika-D3, dan Komputerisasi Akuntansi-D3. Dalam menentukan pilihan program studi yang akan ditempuh ,mahasiswa baru seringkali mengalami kesulitan karena banyaknya pilihan prodi yang ada di FILKOM tersebut.

Beberapa informasi yang diberikan kepada mahasiswa baru diantaranya akreditasi, biaya, prospek, dan keinginan mahasiswanya. Oleh karena itu perlu dirancang sebuah sistem pendukung keputusan yang dapat menentukan salah satu jurusan untuk memberikankan solusi yang terbaik bagi mahasiswa. Sistem pendukung keputusan ini bukanlah untuk menggantikan fungsi dosen, akan tetapi hanya digunakan sebagai alat bantu yang masih terbatas. Metode yang digunakan dalam membuat sistem pendukung keputusan adalah Analytical Hierarchy Process (AHP).

Kriteria, dan Alternatif yang akan membantu mahasiswa baru untuk membantu mempermudah pemilihan jurusan yang tepat bagi mahasiswa tersebut. Selain sistem juga terdapat sebuah hasil rangking pemilihan jurusan yang tepat bagi mahasiswa tersebut Selain sistem juga terdapat sebuah hasil rangking pemilihan jurusan yang tepat bagi mahasiswa itu sendiri[1].

\section{Metode Penelitian}

Dalam penelitian ini akan dilakukan pemecahan masalah terkait dengam pemilihan jurusan Fakultas Ilmu Komputer dengan metode Analytical Hierarchy Process (AHP). Studi yang dilakukan adalah dengan mengumpulkan data sebanyak-banyaknya mengenai faktor-faktor yang menjadi fokus peneliti, hal ini sangat relevan dengan judul penelitian , bahwa peneliti mengkaji permasalahan yang berdasarkan fenomenadan $\mathrm{n}$ faktual yang terjadi dilapangan, yang terjadi dilapangan mengumpulkan data saja tetapi juga menganalisa data yang tidak hanya mengumpulkan data saja tetapi juga menganalisa data yang telah diperoleh tersebut 2 .

Metode AHP merupakan salah satu metode dalam sistem pendukung keputusan yang memiliki keunikan dibandingkan yang lainnya. Hal ini dikarenakan dalam 
pembobotan kriteria, bobot dari setiap kriteria bukan ditentukan di awal tetapi ditentukan menggunakan rumus dari metode ini berdasarkan skala prioritas (tingkat kepentingan) yang bersumberdari table saatt. Metode ini merupakan metode yang sifatnya persepsional, artinya tingkat kepentingan dari suatukriteria tergantungng sudut pandang atau perspektif seseorang dalam menilainya.[3]

Di dalam mengerjakan sebuah penelitian, maka perlu adanya susunan kerangka kerja yang jelas tahapantahapannya. Kerangka kerja ini merupakan langkah-langkah yang akan dilakukan dalam penyelesaian masalah yang akan dibahas. Adapun kerangka kerja penelitian yang akan digunakan sebagai berikut :

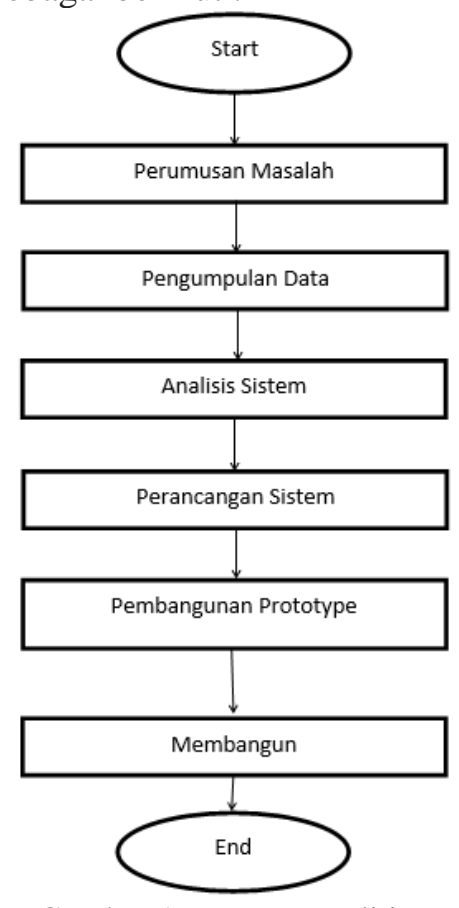

Gambar 1. Proses Penelitian

Dalam penelitian ini menetapkan 4 kriteria yaitu akreditasi, prospek, harga, dan keinginan.

\section{Hasil dan Pembahasan}

Dalam metode AHP dibutuhkan rating kecocokan setiap alternatif penilaian penilaian pada setiap kriteria yaitu berupa nilai dari 1 sampai dengan 9. Untuk lebih jelasnya bisa dilihat dari tabel preferensi tiap kriteria. Dapat dilihat pada tabel preferensi tiap kriteria di bawah.[4]

Tabel 1. Bobot Kriteria

\begin{tabular}{lc}
\hline \multicolumn{1}{c}{ Keterangan Bobot } & Bobot \\
\hline Mutlak sangat penting & 9 \\
\hline Mendekati mutlak dari & 8 \\
\hline
\end{tabular}

\begin{tabular}{ll}
\hline Sangat penting dari & 7 \\
\hline Mendekati sangat penting dari & 6 \\
\hline Lebih penting dari & 5 \\
\hline Mendekati lebih penting dari & 4 \\
\hline Sedikit lebih penting dari & 3 \\
\hline $\begin{array}{l}\text { Mendekati sedikit lebih } \\
\text { penting }\end{array}$ \\
\hline Sama penting \\
$\begin{array}{l}\text { Adapun desain dilakukan menggunakan } \\
\text { ndekatan UML yang dalam hal ini disajikan } \\
\text { lam bentuk use case diagram yang } \\
\text { tunjukan pada Gambar 2. }\end{array}$
\end{tabular}

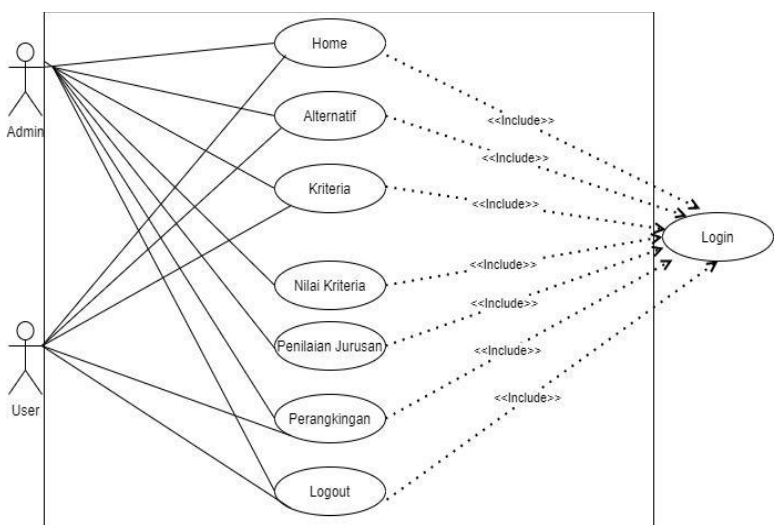

Gambar 2. Use Case Diagram Sistem Pendukung Keputusan pemilihan jurusan

Gambar 3 menunjukan proses activity diagram login admin dan user dengan menginputkan username dan password yang sudah dibuatkan.

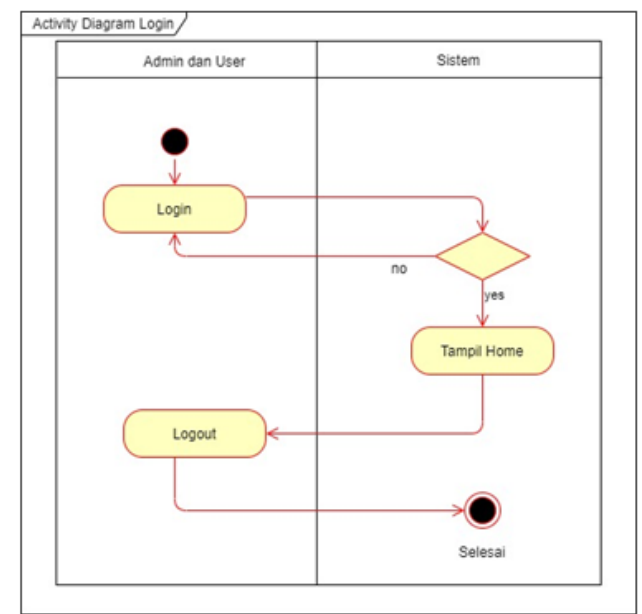

Gambar 3. Activity Diagram login

Gambar 4 adalah diagram penilaian jurusan yang menggunakan diagram sequence. 


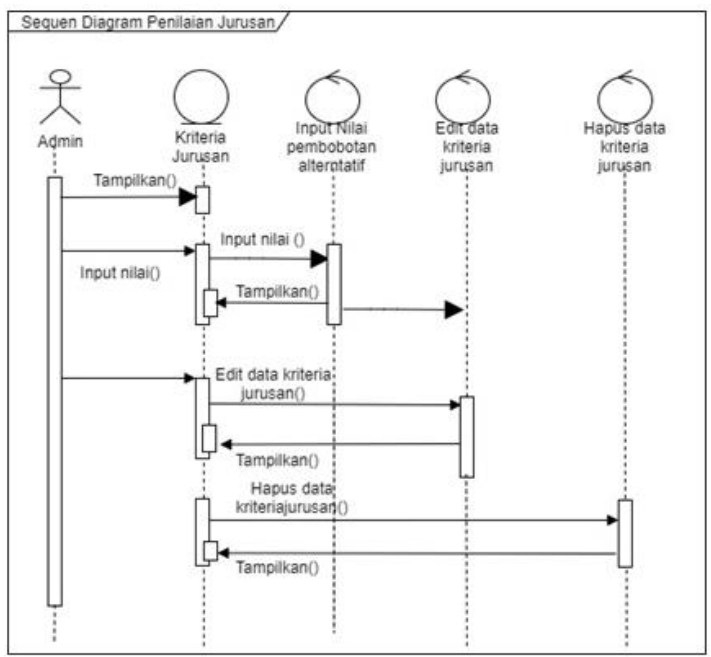

Gambar 4. Diagram Sequence penilaian jurusan Implementasi dilakukan berdasarkan desain sistem yang telah dibuat, yakni dengan melakukan coding untuk membuat aplikasi sesuai dengan use case diagram, activity diagram, dan sequence diagram.[5]

Gambar 5. Tampilan Login Aplikasi

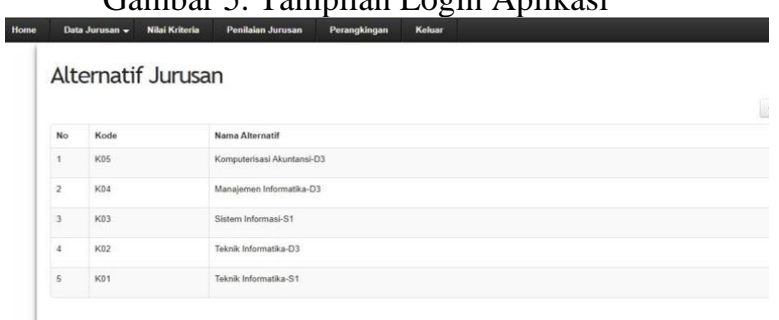

Gambar 6. Input alternatif jurusan

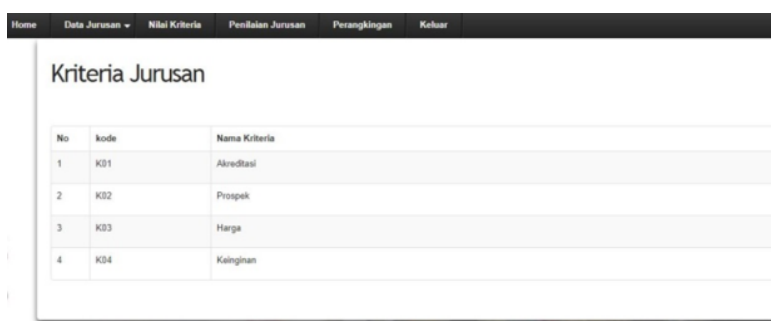

Gambar 7. Input kriteria jurusan
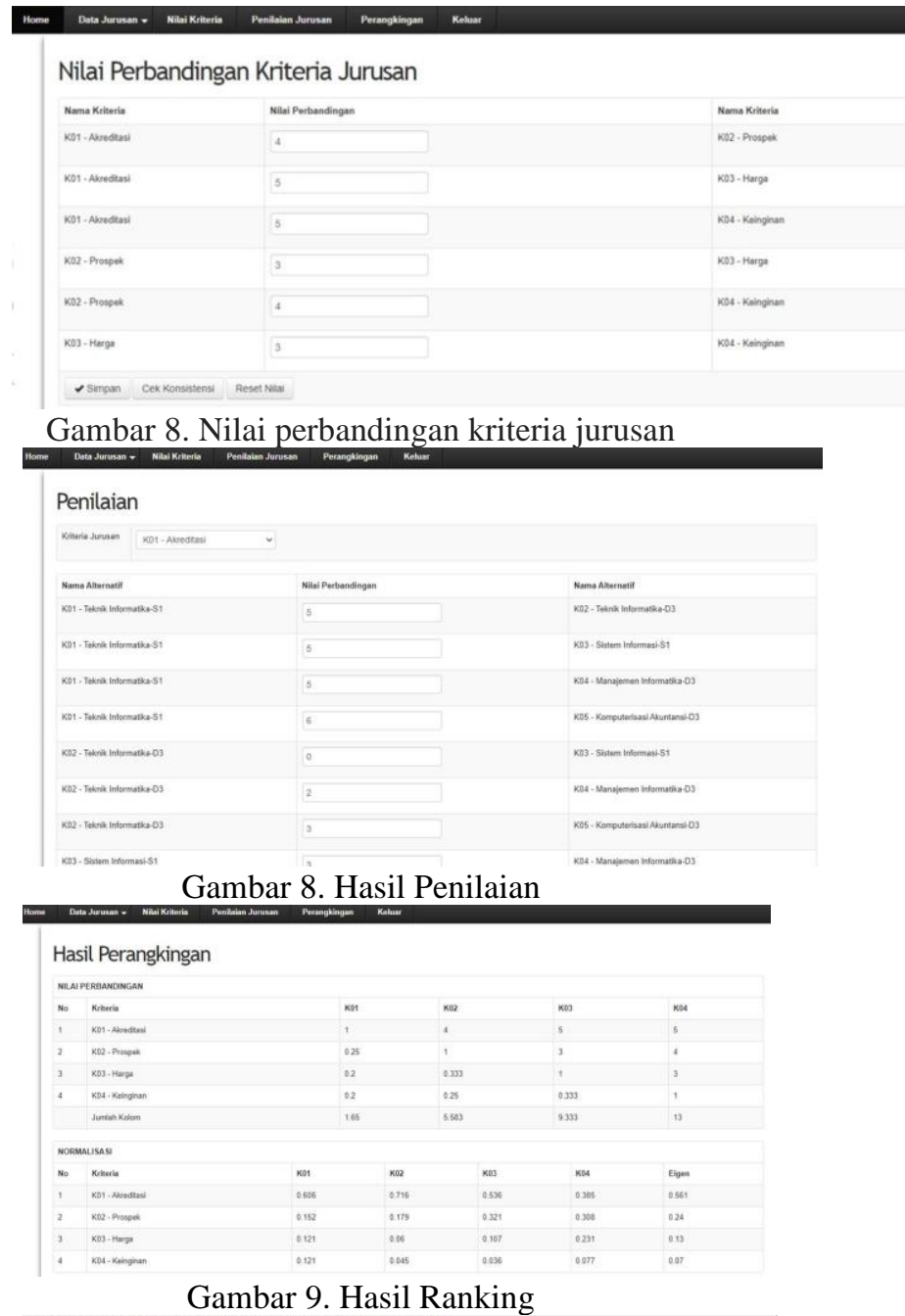
Laporan Hasil Seleksi Jurusan Pada Bulan August
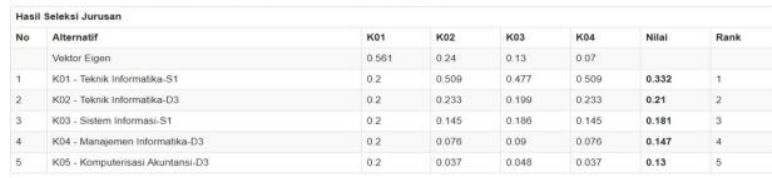

Gambar 10. Laporan Hasil Ranking

\section{Kesimpulan}

Berdasarkan pengamatan dan pengolahan data serta analisis sebelumnya dapat disimpulkan sistem pendukung keputusan ini dibangun dengan menerapkan metode Analytical Hierarchy Process dengan 4 (empat) kriteria yaitu Akreditasi, Prospek, Harga, dan Keinginan dengan4empatkriteriaif sebanyak 5 data yaitu Akreditasi Prospek Harga, Teknik Informatika-D3, Sistem Informasi-S1, Manajemen Informatika-D3, dan Keinginanisasi Akuntansi-D3. Sistem yang dirancang dengan data kode AHP ini mampu memberikan rekomendasi pemilihan jurusan pada UNIVERSITAS BANTEN JAYA dengan nilai tertinggi diperoleh alternatif sebanyak 5 data yaitu 
Teknik Informatika - S1

Teknik Informatika - D3

Sistem Informasi - S1

Manajemen Informatika - D3

Komputerisasi Akuntansi - D3

Sistem yang dirancang dengan metode AHP ini mampu memberikan rekomendasi pemilihan jurusan pada UNIVERSITAS BANTEN JAYA dengan nilai tertinggi diperoleh alternatif Teknik Informatika-S1 dengannilai 0332.

Penelitian ini sejalan dengan penelitian "Implementasi Sistem Pendukung Keputusan Untuk Pemilihan Jurusan Pada Jalur SNMPTN Dengan Metode Analytical Hierarchy Process (Studi Kasus: SMAN 3 Batusangkar), menunjukan bahwa pengambilan keputusan ini mempermudah guru BK dalam mengarahkan siswa untuk memilih jurusan yang tepat sesuai minat dan bakat siswa pada jalur SBMPTN[6].

\section{Daftar Pustaka}

[1] Frieyadie, S.M.Ramadhan, Penerapan Metode AHP Untuk Membantu Siswa Memilih Jurusan Yang Tepat Di SMK Jurnal RESTI (Rekayasa Sistem dan Teknologi Informasi),Vol. 2 No. 3 (2018) 662 - 667, September, 2018.

[2] D. Khuntari and $R$. Ferdiana, Teknik Rekomendasi Pemilihan Jurusan Perguruan Tinggi dengan Pendekatan Preferensi Pengguna dan Analytic Hierarchy Process, Semin. Nas. Teknol. Inf. dan Multimed., vol. 3, no. 1, p. 2.225-2.2-30, 2015
[3] D.Nofriansyah, S.Defit, Multi Criteria Decision Making (MCDM) pada Sistem Pendukung Keputusan, Yogyakarta: CV.Budi Utama, 2017.

[4] A. Wicaksono and N. Aminudin, Perancangan Sistem Pendukung Keputusan Penentuan Jurusan Siswa Sma Pgri 2 Pringsewu Dengan Menggunakan Metode Analytical Hierarchy Proses (AHP, PROCIDING KMSI, vol. 5, no. 1, pp. 16-24, Oktober, 2017

[5] H.Tohari, A.Kudhori, S.G. Wibowo, Aplikasi Paperless Office dalam Implementasi Electronic Office Menggunakan Pendekatan Unified Modelling Language, Smart Comp Vol. 10 No. 3, Oktober ,2021.

[6] S.E. Putri, R.Sovia, A.F.Hadi, Implementasi Sistem Pendukung Keputusan Untuk Pemilihan Jurusan Pada Jalur SNMPTN Dengan Metode Analitycal Hierarchy Process(Studi Kasus: SMAN 3 Batusangkar Seminar Nasional Teknologi Komputer \& Sains (SAINTEKS), Januari, 2019. 